\title{
REPRODUCTION INHIBITING EFFECTS OF DEOXYNIVALENOL OR T-2 TOXIN CONTAMINATED MAIZE ON FOLSOMIA CANDIDA (COLLEMBOLA)
}

\author{
Borbála Szabó ${ }^{\text {, Ramóna Kocsis }}{ }^{1 *}$ and Miklós MÉzes ${ }^{2,3}$ \\ ${ }^{1}$ Szent István University, Department of Zoology and Animal Ecology \\ H-2100 Gödöllő, Páter K. u. 1, Hungary \\ E-mail: szbori001@gmail.com; https://orcid.org/0000-0001-7587-1597; \\ *E-mail: rra.kr.93@gmail.com; https://orcid.org/0000-0002-6704-7888 \\ ${ }^{2}$ Szent István University, Department of Nutrition, H-2100 Gödöllö, Páter Károly u. 1, Hungary \\ ${ }^{3}$ MTA-KE-SZIE Mycotoxins in the Food Chain Research Group \\ H-6400 Kaposvár, Guba Sándor u. 40, Hungary \\ E-mail: Mezes.Miklos@mkk.szie.hu; https://orcid.org/0000-0003-2323-833X
}

In agricultural production, some tillage practices lead to a higher risk to increase the mycotoxin levels in the soil. Mycotoxins, such as T-2 toxin or deoxynivalenol (DON) produced by Fusarium spp., a plant pathogen mould, occur frequently in temperate climates. Folsomia candida is a mainly fungal feeding collembolan, which has a role in the regulation of the soil microbial community and humification. We hypothesized that $F$. candida is adapted to the secondary metabolites of the moulds; therefore, Fusarium mycotoxins do not have an effect on their feed intake and reproduction. OECD experiments were carried out with T-2 or DON-contaminated maize and baker's yeast as an alternative food. An additional experiment was conducted without baker's yeast as well as a food choice test. It was found that DON or T-2 toxin caused significant mortality. Severe impairment in reproduction was also observed, accompanied with mycotoxin contaminated feed refusal. Results of feed refusal themselves cannot be the cause of the low reproduction rate; instead, the mycotoxins most likely impair the embryonic development due to their DNA destructive properties. Additionally, DON and T-2 toxin caused feeding inhibition. Both mycotoxins are known to disturb the dopaminergic and serotoninergic neurons, which may disturb the feeding behaviour, and both trichothecenes can cause lesions in the mouth and gut, which may also resulted feed refusal.

Keywords: mycotoxin, Folsomia, trichothecenes, reproduction, feed refusal

\section{INTRODUCTION}

Mycotoxin contamination of the feed and food is a problem of global extent. Extraordinary weather conditions due to global warming have increased mould infection, and it may cause a steadily increasing rate of mycotoxin contamination of cereals all over the world (Russell et al. 2010). Mycotoxins of plant pathogenic Fusarium moulds, such as 'Type A' trichothecene T-2 toxin and its metabolite HT-2 toxin, or 'type B' trichothecene deoxynivalenol (DON) are common mycotoxins in temperate climates (BINDER et al. 2007). In agricultural production, some tillage practices lead to a higher risk of the 
occurrence of Fusarium moulds, their mycotoxins in soil with infected and contaminated crop residues in the field, which would remain in the field and leach into the soil, becoming potentially dangerous to the environment (STEINKELLER \& LANGer 2004), because mycotoxins in the upper layer of soils can remain relatively stable for a long period (EDwARDs 2004). There are few data available about the effect of mycotoxins on the soil ecosystem (ELMHOLT 2008), however, АвіD et al. (2011) suggested that crop residues contaminated with trichothecene mycotoxins showed an impact on the biotic components of the soil. They found that fungal and bacterial densities were significantly affected by the presence of DON, while the nematodes remained unaffected, but other taxa, such as Collembola, was not investigated earlier.

Folsomia candida Willem, 1902 (Collembola, Isotomidae) is a widely used model animal in soil ecotoxicology (Кrogh 2009, Szabó et al. 2018, Szabó et al. 2019). This species is distributed all over the world in organic matter-rich soils. F. candida is easy to rear in laboratory conditions because of its parthenogenetic way of reproduction, and ease of care (require only baker's yeast as food) (Fountain \& Hopkin 2005, Hopkin 1997, Krogh 2009). F. candida has a role in the humification of organic matter and regulation of microbial community in the soil (HopkIN, 1997). F. candida is a blind, euedaphic collembolan with low dispersion ability, and generally fungal feeding habits (FounTAIN \& НоркIN 2005, НоркIN 1997).

Collembolans are fungivores, which possibly contains mycotoxins as secondary metabolites (InNocenti \& SABATINi 2018, LARSEn et al. 2008). The species Onychiurus armatus (Collembola) can reduce the severity of Fusarium culmorum and Gaeumannomyces graminis var. tritici infection of wheat (SABATINI \& INNOCENTI 2001), which suggest the effective fungivore property of collembolans. However, in the cited experiment, the mycotoxin content of the mould substrate was not verified, so the effects of mycotoxins on collembolan was not revealed. Fungivore species are usually tolerant of the mycotoxins of the preferred fungal species (KARLOvsKY 1999). Therefore it can be expected that $F$. candida is also tolerant to Fusarium mycotoxins.

Meyer-Wolfarth et al. (2017a) found, that F. candida or a nematode Aphelenchoides saprophilus population did not decrease the infection of Fusarium culmorum but earthworm (Lumbricus terrestris) did. In another work of MEYER-Wolfarth et al. (2017b), either F. candida or A. saprophilus with very high starting densities showed inhibition of the effects of F. culmorum infection after four weeks in a single treatment, but not in mixed treatments. However, fauna densities were not given, therefore the effect of F. culmorum, and its main mycotoxin, DON, on the springtail and nematode populations is not clear. Wolfarth et al. (2013) also investigated the effects of DON on the densities of collembolans and nematodes, and they found that the collembolan densities did not decrease but instead mildly increased over the two weeks 
long experiment. However, the results of the above mentioned study were not evaluated correctly, because the embryonic and juvenil development require longer than 14 days period of time to maturation at $17^{\circ} \mathrm{C}$ (Fountain \& HopKIN 2005). In another experiment of WOLFARTH et al. (2015), it was found that the population density was mildly higher after four weeks at the end of the experiment than at the start. However, after four weeks hundreds of juveniles should be present in the containers, at least in the control group, if the springtails are prospering (OECD 2009).

We hypothesized that the predominantly fungal feeding springtail, $F$. candida, adapted to the secondary metabolites of toxicogenic moulds, therefore there are no severe effects of mycotoxins on survival, number of juveniles, food choice, and avoidance of T-2 and DON mycotoxin-contained soil.

\section{MATERIAL AND METHODS}

Folsomia candida (Collembola, Isotomidae) was obtained from the stock population reared in the laboratory of the Szent István University, Department of Zoology and Animal Ecology for the past 35 years. Based on the method of GOTO (1960), collembolans were kept in Petri-dishes (diameter: $9 \mathrm{~cm}$ ), with a mixture of plaster of Paris and activated charcoal (10:1 volume ratio). The animals were kept at a temperature of $20 \pm 0.2^{\circ} \mathrm{C}$ with $\sim 100 \%$ humidity and in darkness. Petri dishes were watered regularly to maintain the humidity at a relatively constant level. The collembolans were fed with dry baker's yeast once per week ad libitum in all treatments. During this operation, they were aerated. All phases of the experiment were performed under the above-mentioned environmental conditions.

The OECD 232 tests (OECD 2009) were performed in OECD standard soil (OECD 2009). The composition of the soil was $74 \%$ sand, $20 \%$ kaolin clay, $5 \%$ sphagnum peat, and $1 \%$ calcium carbonate, at $\mathrm{pH} 7.29$. Thirty gram wet soil was used per jar ( $24.5 \mathrm{~g}$ dry soil, 5.5 $\mathrm{ml}$ tap water, $40 \%$ of Water Holding Capacity). Water holding capacity was measured according to OECD 232 (OECD 2009). Survival and reproduction were measured by counting the number of adults and juveniles after 28 days. The mycotoxin contamination was applied by mixing the contaminated ground maize into the soil. Mycotoxins were produced by the fermentation of maize with a DON producing strain of Fusarium graminearum (NRRL 5883) or with a T-2 toxin-producing strain of Fusarium sporotrichioides (NRRL 3299) according to the method of Szabó-Fodor et al. (2015). DON content was determined according to Pussemier et al. (2011), and T-2 and HT-2 toxin concentration were assayed by the method of TREBSTEIN $e t$ al. (2008) using the HPLC method with fluorescence detection after immunoaffinity clean-up.

Limits of quantification (LOQ) of the measured mycotoxins was DON: $0.160 \mathrm{mg} \mathrm{kg}^{-1}$; T-2 toxin: $0.163 \mathrm{mg} \mathrm{kg}^{-1}$; HT-2 toxin: $0.300 \mathrm{mg} \mathrm{kg}^{-1}$, respectively. The DON concentrations of maize was $16324 \mathrm{mg} \mathrm{kg}^{-1}$ dry matter. For the maize contaminated with T-2 toxin and HT-2 toxin the concentration was $671 \mathrm{mg} \mathrm{kg}^{-1}$ and $0,002 \mathrm{mg} \mathrm{kg}^{-1}$ dry matter, respectively.

There is no guidance value for the mycotoxin content for insect feeds or soil contamination, therefore the lowest concentrations have been chosen for feeds of food-producing animals as given in the recommendations 2006/576/EC and 2013/165/EU (EU 2006, 2013): $12 \mathrm{mg}$ DON kg-1 maize based feed material and $0.50 \mathrm{mg}$ T-2 and HT-2 toxin $\mathrm{kg}^{-1}$ cereal based feed. According to these guidance values, following mycotoxin concentrations were used. In the case of experiments with DON (experiments 1 and 2, see below): 0, 12, 24, 48, 
96, $192 \mathrm{mg} \mathrm{kg}^{-1}$ dry soil, and in the case of experiments with T-2 toxin (experiments 3 and 4 , see below): $0,0.5,1,2,4,8 \mathrm{mg} \mathrm{kg}^{-1}$ dry soil. There were five replicates for the treated jar and ten for control. The experiments were carried out in disposable plastic jars $(100 \mathrm{ml})$, and ten to twelve days old, synchronised animals were used in all experiments. Ten animals were added to each jar.

Four OECD tests were carried out: (1) DON-contaminated maize together with baker's yeast for food, (2) DON-contaminated maize without baker's yeast, (3) T-2 toxin-contaminated maize together with baker's yeast for food, (4) T-2 toxin-contaminated maize without baker's yeast. The ground maize was mixed into the soil. The purpose of the experiments without baker's yeast was to evaluate the toxicity of the contaminated substrate through oral and/or contact toxicity. However, in natural conditions alternative food sources are also available, so an experiment with the usual food, baker's yeast, was performed for a more accurate simulation of the natural conditions. The amount of maize was added based on the actual mycotoxin content to reach the nominal contamination level in the soil, and the amount of yeast was ad libitum added on the soil surface.

Additionally, food choice tests were carried out with mycotoxin contaminated grounded maize and the standard food, baker's yeast, based on the method of BAKоNYI et al. (2011) in Petri dishes (4 cm diameter) on filter paper. There were 20 replicates for both mycotoxin treatments: 20 replicates for DON with a concentration of $16324 \mathrm{mg} \mathrm{kg}^{-1}$ and 20 replicates for the T-2 toxin-contaminated treatment with the concentrations of 671 $\mathrm{mg} \mathrm{kg}^{-1}$ for T-2 toxin and $0.002 \mathrm{mg} \mathrm{kg}^{-1}$ for HT-2 toxin. In total, 40 Petri dishes were used. The length of the experiment was one week. Ten to twelve days old, synchronised animals were used in these experiments. Each animal was kept individually in the Petri dishes, so 40 animals were used in total.

An avoidance test were carried out with the same concentrations as above in the case of the OECD 232 test (DON: 0, 12, 24, 48, 96, 192, T-2: 0, 0.5, 1, 2, 4, $8 \mathrm{mg} \mathrm{kg}^{-1}$ dry soil) with the same OECD soil in disposable plastic jars $(100 \mathrm{ml})$ according to DA Luz et al. (2004). Thirty gram clean and thirty gram contaminated wet soil ( $24.5 \mathrm{~g}$ dry soil, $5.5 \mathrm{ml}$ tap water) separated with a $2 \mathrm{~mm}$ gap was placed in a jar in such a way the animals had a choice between clean versus contaminated OECD soil. Five replicates per treatment and ten per control (uncontaminated soils in both sides) were done. Twenty to twenty-two days old, synchronised animals were used in these experiments. Twenty animals were put in each jar into the middle gap, so arriving spot does not bias the outcome. After 24 hour a plastic divider was inserted in the dividing gap and the animals were collected from the soil of both sides.Test is 48 hour long, so feeding is not necessary.

Statistical analyses for the OECD tests were made using the R Statistical program 3.5.1 (R Development Core Team 2019). The data were analysed with general linear model and the first lowest concentration significantly different from control was accepted as lowest observed effect concentration (LOEC). The whole dataset met the requirements of normality according to the diagnostic plots (Residual variances, QQ plot, and Cook distance plot). $\mathrm{LC}_{50}\left(50 \%\right.$ lethal concentration) and $\mathrm{EC}_{50}$ (50\% effective concentration) values and standard errors were calculated with ToxRat ${ }^{\circledR}$ (ToxRAt ${ }^{\circledR S o l u t i o n s ~ G M в н, ~ 2018) . ~ T h e ~}$ avoidance tests were analysed with paired t-test.

\section{RESULTS}

In the OECD experiments with DON contaminated maize, the survival decreased significantly in a dose-dependent manner, when only the contami- 

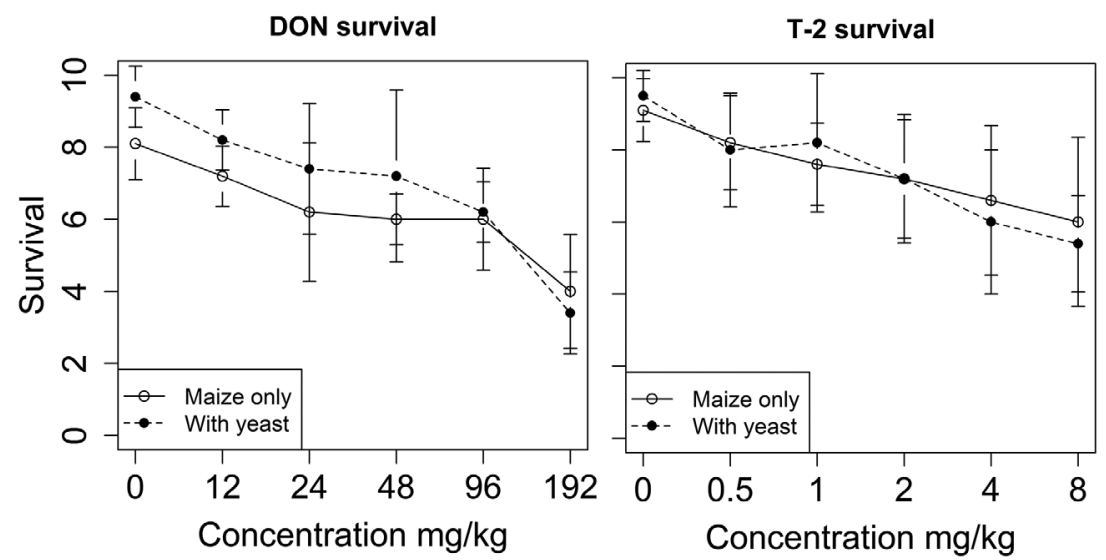

Fig. 1. Results of 28 days long OECD tests. Mean ( \pm standard deviation) of the survival of Folsomia candida exposed to DON or T-2 contaminated maize. The y-axis shows the average number of surviving adults of the ten introduced adults.

nated maize was available $(\mathrm{p}<0.001, \mathrm{t}=-5.6)$ and also when maize was together with yeast $(\mathrm{p}<0.001, \mathrm{t}=-8.2)$. The survival in the two experiments is given in Figure 1. The number of juveniles was also decreased in a dosedependent manner when only maize was available $(p=0.001, t=-3.6)$ and when maize was together with yeast $(p=0.002, t=-3.4)$. The number of juveniles is shown in Figure 2. The $\mathrm{LC}_{50^{\prime}} \mathrm{EC}_{50^{\prime}}$ and $\mathrm{LOEC}$ values are shown in Table 1 . The LOEC of survival or the $\mathrm{LC}_{50}$ did not change when baker's yeast was added as an alternative food. The LOEC of reproduction did not change when baker's yeast was added as an alternative food. However, the $\mathrm{EC}_{50}$ was two-magnitude higher when yeast was added as food, so yeast decreased the toxicity to reproduction.
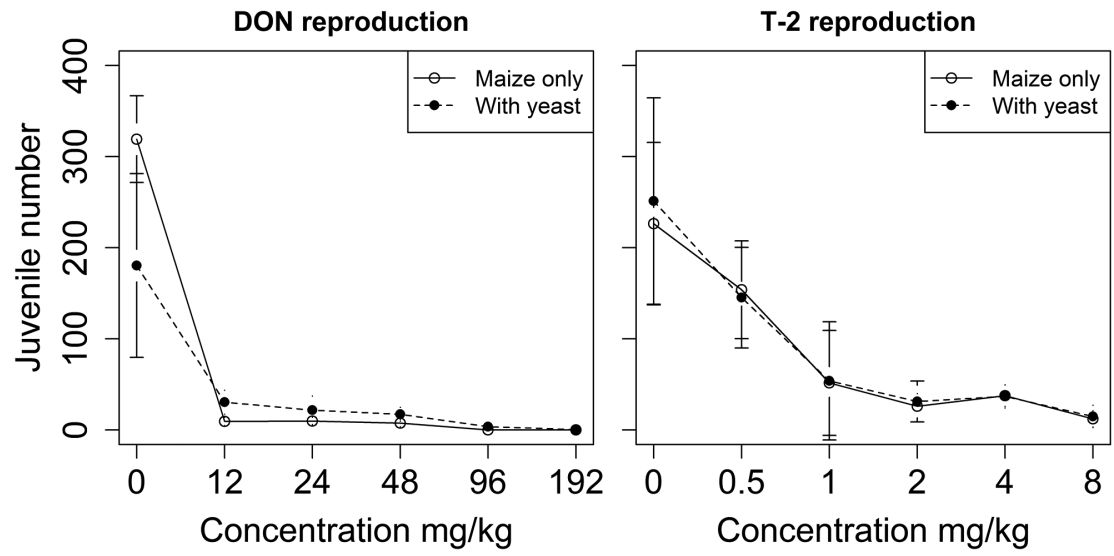

Fig. 2. Results of 28 days long OECD tests. Mean ( \pm standard deviation) of the reproduction (juvenile number) of Folsomia candida exposed to DON or T-2 contaminated maize. 
Table 1. The LOEC, $\mathrm{LC}_{50}$ and $\mathrm{EC}_{50}$ values with confidence intervals (CI) of the OECD tests. The concentrations are given in $\mathrm{mg}$ toxin/ $\mathrm{kg}$ dry soil. nc: not calculable.

\begin{tabular}{lcccccc}
\hline & \multicolumn{3}{c}{ Survival } & \multicolumn{3}{c}{ Reproduction } \\
& LOEC & LC $_{50}$ & $\mathrm{CI}$ & LOEC & $\mathrm{EC}_{50}$ & $\mathrm{CI}$ \\
\hline DON & 24 & 120.4 & $62.6-870.0$ & 12 & 0.01 & $0-550.4$ \\
DON with yeast & 24 & 122.6 & $81.6-248.8$ & 12 & 1.2 & $0-\mathrm{nc}$ \\
T-2 & 2 & $\mathrm{nc}$ & $\mathrm{nc}$ & 0.5 & 0.7 & $0.19-2.3$ \\
T-2 with yeast & 2 & 11.1 & $5.4-92.0$ & 0.5 & 0.5 & $0.06-5.1$ \\
\hline
\end{tabular}

The animals showed feed refusal in the food choice test, consumed only a minimal amount of food (3-4 faeces instead of the usual 35-50), therefore any statistical test would be meaningless.

The animals did not avoid the DON contaminated soil, except at the two highest concentrations $\left(96 \mathrm{mg} \mathrm{kg}^{-1}: \mathrm{p}<0.001, \mathrm{t}=7.4 ; 192 \mathrm{mg} \mathrm{kg}^{-1}: \mathrm{p}<0.001, \mathrm{t}=\right.$ 11.9).

In the case of the OECD tests with T-2 toxin contaminated maize, the survival decreased significantly in a dose-dependent manner in both experiments when only contaminated maize was available $(\mathrm{p}<0.001, \mathrm{t}=-3.8)$ and when it was given together with yeast $(p<0.001, t=-5.1)$. The reproduction also revealed dose-dependent decrease when only $\mathrm{T}-2$ toxin-contaminated maize was available $(\mathrm{p}<0.001, \mathrm{t}=-4.5)$ and when together with yeast was given as well $(\mathrm{p}<0.001, \mathrm{t}=-4.1)$. The $\mathrm{LC}_{50^{\prime}} \mathrm{EC}_{50^{\prime}}$ and $\mathrm{LOEC}$ values are shown in Table 1. Neither the LOEC nor the $\mathrm{LC}_{50}$ (out of concentration range in both feeding group) of the survival was different when baker's yeast was added as an alternative food. The $\mathrm{EC}_{50}$ was not different in the two feeding groups.

The animals showed feed refusal and consumed only a minimal amount of food, which was proven by the number of faeces (3-4 instead of the usual $35-50)$, therefore evaluating a statistical test would not have a meaning.

The animals did not avoid the T-2 toxin-contaminated soil within the contamination regime used in the experiment.

\section{DISCUSSION}

The results revealed that both trichothecene mycotoxins, DON and T-2 toxin, caused low mortality comparing to reproduction, but high impairment of reproduction, and feed refusal. These effects can be explained by the mode of action of trichothecene mycotoxins. For instance T-2 toxin and DON inhibit proteins, DNA and RNA synthesis, can cause cytotoxicity, immune suppression, lesions in the digestive tract, neural disturbances and low performance traits, as was found in vertebrates (DiAz et al. 1994, SzABó-Fodor et al. 2015, 
Sokolović et al. 2008, Speijers \& Speijers 2004). However, data is rarely available about effects on insects, such as collembolan. In the present study, DON and T-2 toxin, at the applied dose range, caused relatively low mortality in F. candida. In the case of both mycotoxins, neither the LOEC nor the $\mathrm{LC}_{50}$ values changed when baker's yeast was added as an alternative food, which suggested that mortality could not be the only consequence of feed refusal. In the case of T-2 toxin, the $\mathrm{LC}_{50}$ value was out of the concentration range used in this study ( 0.5 to $8 \mathrm{mg} \mathrm{kg}^{-1}$ soil). In the case of DON, the $\mathrm{LC}_{50}$ value was far above (approximately 20-times) the recommended feed contamination limit level (5 $\mathrm{mg} \mathrm{kg}^{-1}$ ) for food-producing animals (EU 2006, SoKolović et al. 2008). In contrast to mortality, the reproduction of $F$. candida was impaired dramatically as an effect of both trichothecene mycotoxins, and the LOEC value of reproduction was at the lowest concentration applied. In the case of T-2 toxin, $\mathrm{EC}_{50}$ value was around the recommended limit value for vertebrates as given by the European Commission Recommendations (2013/165/EU). The reproduction of F. candida was impaired as an effect of T-2 toxin exposure, and the decrease of juveniles suggest high sensitivity to $\mathrm{T}-2$ toxin. The $\mathrm{EC}_{50}$ value of $\mathrm{DON}$ was very low in both experimental groups $\left(1.2 \mathrm{mg} \mathrm{kg}^{-1}\right.$ and $\left.0.01 \mathrm{mg} \mathrm{kg}^{-1}\right)$ which is much lower than the recommended limit for vertebrates (EU 2006). These low $\mathrm{EC}_{50}$ values revealed high sensitivity in $F$. candida. Also, there is a three-magnitude difference in the $\mathrm{EC}_{50}$ value of the two feeding groups, which means that the good quality food could decrease the toxicity of DON to reproduction.

According to the food choice experiment, marked feed refusal was found when using the mycotoxin contaminated maize. However, the food choice experiment lasted only for one week, which was shorter than the four weeks long OECD tests. Otherwise, the feed intake could have dramatically increased if the feed refusal ceased. In this case the animals could have grazed the baker's yeast which could also have supported the refusal of contaminated maize. Application of additional yeast did not increase the survival, but it had a positive effect on the reproduction of DON treated groups. Most probably, the alternative food source may help to gain energy to lay more eggs. However, in the present study, only the number of juveniles were measured, so to verify this hypothesis requires further experiments.

A possible explanation for the low reproduction rate caused by both mycotoxins is the impaired ability to hatch from the eggs, due to DNA damaging effect. This hypothesis is partly supported by the low number of juveniles in the present study, however, to verify this hypothesis further experiments are required.

The feed refusal effect of trichothecene mycotoxins is well known in vertebrates (Diaz et al. 1994, Szabó-Fodor et al. 2015, Soкolović et al. 2008). The biochemical mechanism in vertebrates is that T-2 toxin overstimulates 
the serotoninergic neurons, which can cause lack of appetite (Dinz et al. 1994, Sмітн 1992, Soкоlović et al. 2008). However, the serotoninergic system has also influenced the regulation of feed intake in arthropods (Mizunami $e t$ al. 2009, NÄssel 1988, Schroll et al. 2006, UNOKI et al. 2005, 2006), therefore possibly the same mechanism caused the feed refusal in F. candida. The basis of this mechanism is that mycotoxins block the positive chemical feedbacks, which are necessary for feed intake (Simpson \& Bernays 1983). Another possible explanation is that blocking the emptying of hindgut gives negative feedback through the stretch receptors (Audsley \& Weaver 2009, Simpson \& Bernays 1983). The other trichothecene, DON, stimulates the dopaminergic system in vertebrates, which is responsible for reward/punishment and aversion to a particular food. The dopaminergic system has the same function in arthropods (Mizunami et al. 2009, UnOKi et al. 2005, 2006); therefore, DON could make negative conditioning of feed intake even in collembolans. However, this negative conditioning probably resolved after a particular period of time, which may cause the difference in feed intake between the two feeding groups. Thus, when yeast is added as an alternative food, the aversion is resolved in time, and the animals could acquire the necessary energy for reproduction.

Trichothecene mycotoxins, in particular, T-2 toxin, cause lesions in the gastric system in a dose-dependent manner, as it was proven in vertebrates (Diaz et al. 1994, Sмітн 1992, Soкоlović et al. 2008). These lesions may have occurred in F. candida, too. However, if an alternative food, such as yeast, was available, the feed intake could have increased with time, possibly after the lesions are healed.

The fact that $F$. candida did not consume the contaminated food and had a very low reproduction could be the reason that $F$. candida did not affect the amount of Fusarium in the soil experiment of Meyer-Wolfarth (2017a). Also, this would be the reason that the number of collembolans did not increase remarkably as it is shown in the dataset of Wolfarth et al. $(2013,2015)$.

We hypothesized that F. candida is tolerant to trichothecene mycotoxins as a fungal feeding species (KARLOVSKY 1999). However, the results of the present study revealed regarding reproduction, $F$. candida seems to be very sensitive. The reason for this sensitivity could be the antifungivore function of mycotoxins (Rohlfs et al. 2007, Vega \& Mercadier 1998). Döll et al. (2013) have found that secondary metabolite production of Aspergillus nidulans increased if F. candida was grazing on it. In the current experiment, the moulds were inactive, when added to the soil, but it is possible that Fusarium sp. is also able to adjust the secondary metabolite production as defence from fungivores. Moreover, neither Fusarium graminearum, nor Fusarium sporotrichioides are soil-borne pathogens, which may result in relatively low tolerance of $F$. candida to the exposure of their secondary metabolites, in particular in the case of reproduction. 


\section{CONCLUSIONS}

The results of the present study suggest that DON or T-2 toxin caused mortality in F. candida. Moreover, both mycotoxins decreased the reproduction due to feed refusal, causing a lack of nutrients and energy. Otherwise, we speculated that trichothecene mycotoxins impaired the embryonic development through damaging the DNA. In conclusion, the population of collembolans is affected in the presence of trichothecene mycotoxins as DON and $\mathrm{T}-2$ in the soil. Under certain conditions, mycotoxins may have a negative impact on the soil ecosystem.

Acknowledgements - The research was supported by the grant NVKP_16-1-20160016 of the Hungarian National Research, Development and Innovation Office. We would like to thank for the two anonymous reviewers for their kind suggestions on improving the manuscript. Many thanks to David Ospina from Cornell University, NY, for grammatical corrections in English.

\section{REFERENCES}

Abid, M., Leplat, J., Fayolle, L., Gautheron, E., Heraud, C., Gautheron, N., Edel-Hermann, V., Cordier, C. \& SteinberG, C. (2011): Ecological role of mycotoxins in wheat crop residues: consequences on the multitrophic interactions and the development of Fusarium graminearum. - Multitrophic Interactions in Soil IOBC Bulletin 71: 1-5.

Bakonyi, G., Dolezsai, A., Mátrai, N. \& SzéKács, A. (2011): Effects of consumption of Btmaize (MON 810) on the Collembolan Folsomia candida, over multiple generations: a laboratory study. - Insects 2: 243-252. https://doi.org/10.3390/insects2020243

Binder, E. M., TAN, L. M., Chin, L. J., HANdL, J. \& Richard, J. (2007): Worldwide occurrence of mycotoxins in commodities, feeds and feed ingredients. - Animal Feed Science and Technolology 137: 265-282. https://doi.org/10.1016/j.anifeedsci.2007.06.005

da Luz, T. N., Ribeiro, R., Sousa, J. P., Riberio, R. \& Sousa, J. P. (2004): Avoidance tests with Collembola and earthworms as early screening tools for site-specific assessment of polluted soils. - Environmental Toxicology and Chemistry 23: 2188-2193. https://doi. org/10.1897/03-445

Diaz, G. J., Julian, R. J., Squires, E. J. \& Boermans, H. J. (1994): Individual and combined effects of T-2 toxin and das in laying hens. - British Poultry Science 35: 393-405. https:// doi.org/10.1080/00071669408417704

Döll, K., Chatterjee, S., Scheu, S., Karlovsky, P. \& Rohlfs, M. (2013): Fungal metabolic plasticity and sexual development mediate induced resistance to arthropod fungivory. - Proceedings of the Royal Society B: Biological Sciences 280: 20131219. https://doi. org/10.1098/rspb.2013.1219

EDwARDS, S. G. (2004): Influence of agricultural practices on fusarium infection of cereals and subsequent contamination of grain by trichothecene mycotoxins. - Toxicology Letters 153: 29-35. https://doi.org/10.1016/j.toxlet.2004.04.022 
Elmholt, S. (2008): Mycotoxins in the soil environment. Pp. 167-203. In: Karlovsky, P. (ed.): Secondary metabolites in soil ecology. Soil biology. - Springer, Berlin, Heidelberg. https://doi.org/10.1007/978-3-540-74543-3_9

EU (2006): Commission recommendation of 17 August 2006 on the presence of deoxynivalenol, zearalenone, ochratoxin A, T-2 and HT-2 and fumonisins in products intended for animal feeding (2006/576/EC). - Official Journal of the European Union L229/7

EU (2013): Commission recommendation of 27 March 2013 on the presence of T-2 and HT-2 toxin in cereals and cereal products (2013/165/EU). Official Journal of the European Union $\mathrm{L} 91 / 12$

Fountain, M. T. \& Hopkin, S. P. (2005): Folsomia candida (Collembola): a "standard" soil arthropod. - Annual Review of Entomology 50: 201-222. https://doi.org/10.1146/annurev.ento.50.071803.130331

Gото, H. E. (1960): Simple techniques for the rearing of Collembola and a note on the use of a fungistatic substance in the cultures. - Entomologist's Monthly Magazine 96: 138-140.

Hopkin, S. P. (1997): Biology of the springtails (Insecta: Collembola). - Oxford University Press, Oxford, 344 pp.

Innocenti, G. \& Sabatini, M. A. (2018): Collembola and plant pathogenic, antagonistic and arbuscular mycorrhizal fungi: A review. - Bulletin of Insectology 71: 71-76.

Karlovsky, P. (1999) Biological detoxification of fungal toxins and its use in plant breeding, feed and food production. - Natural Toxins 7: 1-23. https://doi.org/10.1007/ s00253-011-3401-5

Krogh, P. H. (2009): Toxicity testing with the collembolans Folsomia fimetaria and Folsomia candida and the results of a ringtest. - Danish Ministry of Enviroment Enviromental Project No. 1256 2009, 66 pp.

Larsen, J., Johansen, A., Larsen, S. E., Heckmann, L. H., Jakobsen, I. \& Krogh, P. H. (2008): Population performance of collembolans feeding on soil fungi from different ecological niches. - Soil Biology and Biochemistry 40: 360-369. https://doi.org/10.1016/j. soilbio.2007.08.016

Meyer-Wolfarth, F., Schrader, S., Oldenburg, E., Weinert, J. \& Brunotte, J. (2017a): Biocontrol of the toxigenic plant pathogen Fusarium culmorum by soil fauna in an agroecosystem. - Mycotoxin Research 33: 237-244. https://doi.org/10.1007/s12550-0170282-1

Meyer-Wolfarth, F., Schrader, S., Oldenburg, E., Weinert, J. \& Brunotte, J. (2017b): collembolans and soil nematodes as biological regulators of the plant pathogen Fusarium culmorum. - Journal of Plant Diseases and Protection 124: 493-498. https://doi. org/10.1007/s41348-017-0111-y

Mizunami, M., Unoki, S., Mori, Y., Hirashima, D., Hatano, A. \& Matsumoto, Y. (2009): Roles of octopaminergic and dopaminergic neurons in appetitive and aversive memory recall in an insect. - BMC Biolology 7: 1-16. https://doi.org/10.1186/1741-7007-7-46

OECD (2009): Guidelines for testing chemicals-Collembola reproduction test in soil: 232. The Organisation for Economic Co-operation and Development (OECD), Paris.

Pussemier, L., Piérard, J.-Y., Anselme, M., Tangni, E. K., Motte, J.-C. \& Larondelle, Y. (2006): Development and application of analytical methods for the determination of mycotoxins in organic and conventional wheat. - Food Additives $\mathcal{E}$ Contaminants 23: 1208-1218. https://doi.org/10.1080/02652030600699312

R Development Core Team (2019): R: A language and environment for statistical computing. - R Foundation for Statistical Computing, Vienna, Austria, https://www.Rproject.org 
Rohlfs, M., Albert, M., Keller, N. P. \& Kempken, F. (2007): Secondary chemicals protect mould from fungivory. - Biology Letters 3: 523-525. https://doi.org/10.1098/ rsbl.2007.0338

Russell, R., Paterson, M. \& Lima, N. (2010): How will climate change affect mycotoxins in food? - Food Research International 43: 1902-1914. https://doi.org/10.1016/j. foodres.2009.07.010

Sabatini, M. A. \& InNocenti, G. (2001) Effects of Collembola on plant-pathogenic fungus interactions in simple experimental systems. - Biology and Fertility of Soils 33: 62-66. https://doi.org/10.1007/s003740000290

Sмiтн, T. K. (1992): Recent advances in the understanding of Fusarium trichotehecne mycotoxicoses. - Journal of Animal Science 70: 3989-3993. https://doi.org/10.1176/appi. focus.12.1.3

Sokolović, M., Garaj-Vrhovac, V. \& Šimpraga, B. (2008): T-2 toxin: Incidence and toxicity in poultry. - Arhiv za higijenu rada i toksikologiju 59: 43-52. https://doi.org/10.2478/100041254-59-2008-1843

Steinkellner, S., LANGer, I. (2004): Impact of tillage on the incidence of Fusarium spp. in soil. - Plant and Soil 267: 13-22. https://doi.org/10.1007/s11104-005-2574-z

Szabó, B., Seres, A. \& Bakonyi, G. (2018): Folsomia candida (Collembola) locomotor activity pattern is changed by a neurotoxicant pesticide. - Acta Zoologica Academiae Scientarium Hungaricae 64: 355-368. https://doi.org/10.17109/AZH.64.4.355.2018

Szabó, B., Lang, Z., Bakonyi, G., Märien, J., Roelofs, D., van Gestel, C.A.M. \& Seres, A. (2019): Transgenerational and multigenerational stress gene responses to the insecticide etofenprox in Folsomia candida (Collembola). - Ecotoxicology and Environmental Safety 175: 181-191. https://doi.org/10.1016/j.ecoenv.2019.03.052

Szabó-Fodor, J., Kachlek, M., Cseh, S., Somoskôi, B., Szabó, A., Blochné Bodnár, Z., Tornyos, G., Mézes, M., Balogh, K., Glávits, R., Hafner, D. \& Kovács, M. (2015): Individual and combined effects of subchronic exposure of three fusarium toxins (fumonisin B, deoxynivalenol and zearalenone) in rabbit bucks. - Journal of Clinical Toxicology 5: 264. https://doi.org/10.4172/2161-0495.1000264

ToxRat ${ }^{\circledR}$ Solutions Gmbн (2018) ToxRat Professionals 3.3.0. https://www.toxrat.com/software-72.html

Trebstein, A., Seefelder, W., Lauber, U. \& Humpf, H.-U. (2008): Determination of T-2 and HT-2 toxins in cereals including oats after immunoaffinity cleanup by liquid chromatography and fluorescence detection. - Journal of Agricultural and Food Chemistry 56: 4968-4975. https://doi.org/10.1021/jf800316m

Ueno, Y., Nakayama, K., Ishi, K., Tashiro, F., Minoda, Y., Omori, T. \& Komagata, K. (1983): Metabolism of T-2 toxin in Curtobacterium sp. strain 114-2. - Applied Environmental Microbiology 46: 120-127.

Unокi, S., Матsumoto, Y. \& Mizunami, M. (2005): Participation of octopaminergic reward system and dopaminergic punishment system in insect olfactory learning revealed by pharmacological study. - European Journal of Neuroscience 22: 1409-1416. https:// doi.org/10.1111/j.1460-9568.2005.04318.x

Unoкi, S., Mатsumoto, Y. \& Mizunami, M. (2006): Roles of octopaminergic and dopaminergic neurons in mediating reward and punishment signals in insect visual learning. - European Journal of Neuroscience 24: 2031-2038. https://doi.org/10.1111/j.14609568.2006.05099.x

Vega, F. E. \& Mercadier, G. (1998): Insects, coffee and ochratoxin A. - Florida Entomologist 81: 543-544. https://doi.org/10.2307/3495953 
Wolfarth, F., Schrader, S., Oldenburg, E. \& Weinert, J. (2013): Nematode-collembolaninteraction promotes the degradation of Fusarium biomass and deoxynivalenol according to soil texture. - Soil Biology and Biochemistry 57: 903-910. https://doi. org/10.1016/j.soilbio.2012.11.001

Wolfarth, F., Wedekind, S., Schrader, S., Oldenburg, E. \& Brunotte, J. (2015): Regulation of the mycotoxin deoxynivalenol by Folsomia candida (Collembola) and Aphelenchoides saprophilus (Nematoda) in an on-farm experiment. - Pedobiologia 58: 41-47. https://doi.org/10.1016/j.pedobi.2015.01.003

Received April 9, 2019, accepted September 11, 2019, published November 22, 2019 